\title{
Economic Empowerment of Indigenous Papuan Women "Mama Papua" in West Papua: Islamic Financial Perspective
}

Submitted 23/08/20, $1^{\text {st }}$ revision 03/09/20, $2^{\text {nd }}$ revision 28/09/20, accepted 20/10/20

\author{
Hamzah $^{1}$, St. Umrah ${ }^{2}$, Agus Yudiawan ${ }^{3}$
}

\begin{abstract}
:
Purpose: Papuan women have a dual role in the family. Apart from being a mother, she is also the breadwinner for her family. Selling local agricultural products in traditional markets is their primary source of uncertain income. This condition is motivated by unpreparedness and competition with the transmigrants who live in the area. In general, this study aims to explore and offer a model for empowering indigenous Papuan women in improving the economy. The empowerment model referred to is linked to the perspective of Islamic finance.

Approach/Methodology/Design: The research method is qualitative with interview techniques in collecting data. As many as 15 Papuan mothers from the Kokoda tribe in traditional markets were used as informants. Furthermore, the data collected was analyzed in three stages, namely: data reduction, data presentation, concluding/verification.

Findings: The results showed that 1) the products that mama Papua sold were agricultural products. Sold traditionally in storefronts or roadside stalls 2) income from sales is used to meet the needs for clothing, food, children's education, business capital, and family savings; and 3) empowerment of "mama Papua" can be done through a) providing access to capital through donations and banking, and b) ongoing assistance with stakeholders focused on optimizing business ethos, developing economic attitudes and skills in product sales.

Practical Implications: The implication is that "mama Papua" as an entity of indigenous Papuans can compete (independently) in his own hands if marketing competence can be improved through various sustainable parties' involvement.

Originality/Value: Capital assistance through infaq and banking and stakeholder support are key instruments in increasing Papuan women's businesses in traditional markets.
\end{abstract}

Keywords: Economic Empowerment, Islamic Finance, Indigenous Papuan Women

Paper Type: Research article.

ISSN: 2241-4754, H Index 10, Q3.

\footnotetext{
${ }^{1}$ Faculty of Economics and Islamic Business, Alauddin State Islamic University Makassar, Indonesia, umrah-hasankhaeriyah@gmail.com

${ }^{2}$ Majoring in Syariah, Sorong State Islamic Institute, West Papua, Indonesia, umrahhasankhaeriyah@gmail.com

${ }_{3}^{3}$ Majoring in Tarbiyah, Sorong State Islamic Institute, West Papua, Indonesia, agusyudiawan@stainsorong.ac.id
} 


\section{Introduction}

Traditional economic actors between immigrants and indigenous Papuans in West Papua experience extremely high disparities. Migrants (transmigrant residents) tradein clean and orderly shops, while native Papuan women are only trampled in the slum and improper stalls (Samori, 2019). The results of field observations in early July 2020 at the Remu Traditional Market in Sorong City found that most native Papuan traders were selling on the side of the road and in front of the shop. Likewise, at the Aimas Traditional Market, native Papuan sellers trade their sales at stalls made of wood or on noken (original Papuan bags) without a roof. It can be ascertained that if it rains, the sales will shift to the shops belonging to the migrant community.

Furthermore, Chotim's research report states that the inequality of immigrants and indigenous Papuans' economic actors is extremely high so that the indigenous Papuans seem to be "marginalized" (Chotim, 2020). This condition requires improvements in all sectors. Strengthening the economy of indigenous Papuan women is imperative. The goal is that healthy competition can be generated, especially in increasing native Papuan traders' productivity on their land.

Here, Papuan women have a dual function, apart from being housewives but the backbone of the family's economy (Pahri, 2017). As family members, they educate their children and take care of the internal family, and on the other hand, they participate in strengthening the family economy. The involvement of the business world in coaching mama Papua is still minimal. For example, PT. Freeport assists in empowering mama Papua in terms of selling betel nuts (a typical Papuan food). Tina According to a Papuan figure, Yoku, felt greatly helped by the coaching carried out by PT Freeport in collaboration with banks (Jppn.com, 2018). However, how is the "mama Papua" coaching model in the traditional market? It is crucial to conduct an in-depth study as a solution to overcome economic disparities between ethnic groups.

Studies on the relationship between women's economic actors' empowerment and Islamic finance are widely carried out in various regions. First, Islamic finance is seen as a resource mobilization tool (Gundogdu, 2018). With this model, it focuses on efforts to stretch the economy in the micro aspect. Second, Islamic finance through Islamic microfinance institutions as an instrument for empowering women (Rahayu, 2020; Nugroho and Chowdhury, 2015). The assumption is that providing affordable financial services for the poor is essential in increasing the poor's productivity and enhancing poor Muslims' economic development (Ahmed and Ammar, 2015). However, existing studies have not positioned Islamic finance as an instrument of empowering native Papuan women. Several studies still highlight the issue of fulfilling the basic economic rights of native Papuan families (Wambrauw et al., 2019; Suryawan, 2017; Chotim, 2020), women's financial motivation (Wulan and Muafa, 2020), and trade commodities in Papuan market, (Blesia and Ratang, 2016). Here native Papuan women are always in a marginalized condition (Chotim, 2020). The inability to compete with business actors (from migrant residents) makes native 
Papuan women only able to sell areca nut and garden products (Jppn.com, 2018; Blesia and Ratang, 2016). The conclusion is that Papuan women are not economically empowered and increasingly marginalized in their land. Optimization of the competence of trafficking of indigenous Papuan women must continue to be encouraged through various financial instruments that better defend the poor.

This study is based on the argument that native Papuan women "mama Papua" can compete if supported by credible financial instruments. The instrument referred to is empowerment assistance through donations and sustainable stakeholder support (Rahayu, 2020). As stated by Ahmed, E. M., and Ammar, capital through donations can positively contribute to micro and traditional businesses (Ahmed and Ammar, 2015). The infaq model is considered relevant for the "mama Papua" community to increase capital and empowerment (Blesia and Ratang, 2016). Also, the stakeholders' role is in the form of assistance in sales skills and microeconomic science (Pahri, 2017). The reason is that the indigenous Papuan people's mindset only puts forward their will rather than their needs to low economic competitiveness (Wulan and Muafa, 2020). Thus, the model of sustainable mentoring and funding from an Islamic perspective (infaq) can be a practical choice to answer existing problems.

This paper aims to complement previous research. Where will focus on the vibrant economy of native Papuan women (Mama Papua)? Apart from identifying a viable economy, it also shows a significant economic development model for "mama Papua," especially for women of the Kokoda tribe. In other words, this paper provides a reasonable offer in improving the competence of Papuan women (mama Papua) in running a business in the traditional markets of West Papua.

\section{Research Method}

This study is based on the argument that native Papuan women "mama Papua" can compete if supported by credible financial instruments. The instrument referred to is empowerment assistance through donations and sustainable stakeholder support (Rahayu, 2020). As stated by Ahmed, E. M., and Ammar, capital through donations can positively contribute to micro and traditional businesses (Ahmed and Ammar, 2015). The infaq model is considered relevant for the "mama Papua" community to increase capital and empowerment (Blesia and Ratang, 2016). Also, the stakeholders' role is in the form of assistance in sales skills and microeconomic science (Pahri, 2017). The reason is that the indigenous Papuan people's mindset only puts forward their will rather than their needs to low economic competitiveness (Wulan and Muafa, 2020). Thus, the model of sustainable mentoring and funding from an Islamic perspective (infaq) can be a practical choice to answer existing problems.

This paper aims to complement previous research. Where will focus on the vibrant economy of native Papuan women (mama Papua)? Apart from identifying a viable economy, it also shows a useful economic development model for "mama Papua," especially for women of the Kokoda tribe. In other words, this paper provides a 
reasonable offer in improving the competence of Papuan women (mama Papua) in running a business in the traditional markets of West Papua.

Figure 1. Miles and Huberman's Interactive Data Analysis Model

Source: Own creation.

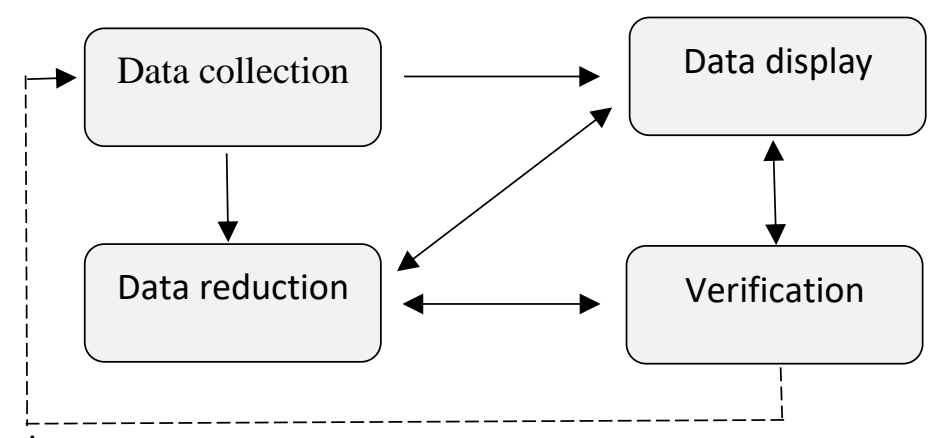

\section{Results and Discussion}

The economic conditions in the traditional market of "mama Papua" Aimas describe contradictory situations to non-Papuan traders. The original Papuan sellers were more focused on selling horticultural vegetables, which were improvised. However, the proceeds from selling become the primary source of livelihood in meeting family's needs. A distribution of the need for "mama Papua" for the Kokoda Tribe in Aimas Traditional Market is shown in Figure 2:

Figure 2. Distribution of the Need for "mama Papua" for the Kokoda Tribe in Aimas Traditional Market

(1) Sources of Selling Goods (\%)

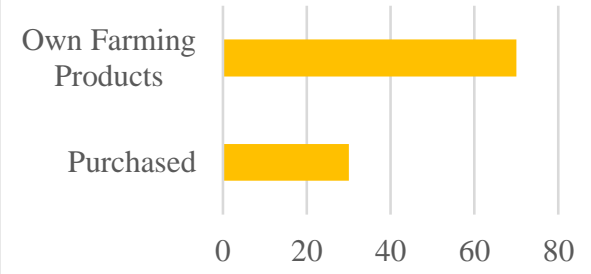

(3) Allocation (\%)

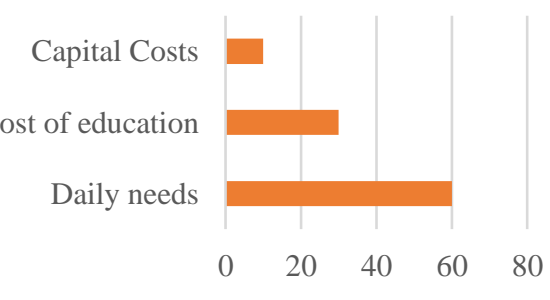




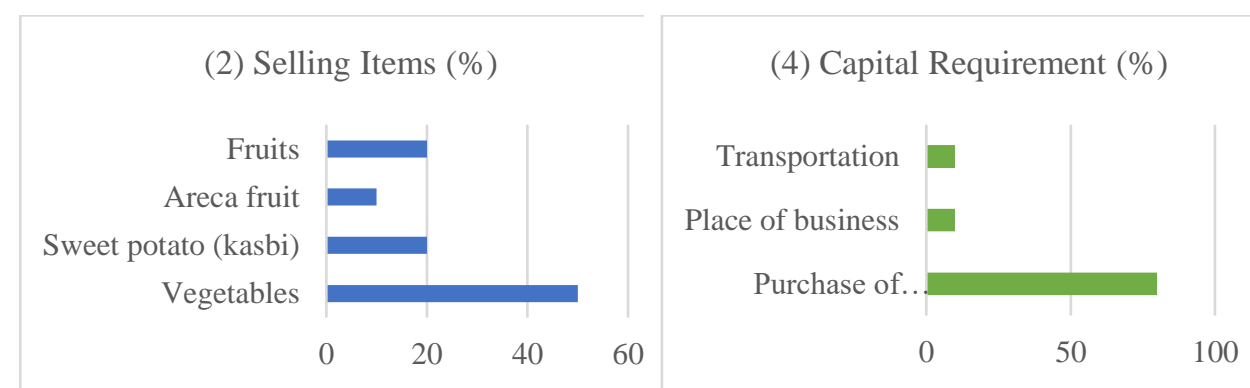

Source: Processed by researchers (2020).

\subsection{Economic Conditions of the Traditional Market "Mama Papua"}

Geo-economically, Aimas is an area that supplies vegetables for the City and Regency of Sorong. Farmers consisting of transmigration and immigrant community descendants and indigenous Papuans are actors contributing to realizing the area. The supply of vegetables in the surrounding area is obtained from the "mama Papua" traditional market, especially for sweet potatoes and vegetables and bananas, local crops.

Meanwhile, for other vegetable needs such as carrots, green beans, and potatoes outside Papua (Datu, 2020). Interestingly, in this traditional market, "mama Papua" apart from being a seller, is also a distributor and producer (farmer).

\section{a. Manufacturer}

Theoretically, economics teaches that cooperation makes it possible to produce output or production (Hasibuan, 1987). Labor, as the dominant economic factor, influences the dynamics of other factors to boost production. In the agricultural economy, farmers can also be seen as producers because they have produced goods to be distributed to the market. The mobilization of products traded by mama Papua sellers can be seen in Figure 2 (1) above. The mama Papua seller sells vegetables from his own garden as much as $70 \%$, while only $30 \%$ of the proceeds from the purchase. In general, their tendency is not only as producers but also as sellers. The informant (Ramli, 2020) stated planting on limited crops such as papaya, banana, and areca nut.

This plant produces derivative for sale, which is categorized as vegetables and fruit. Especially for cassava, they tend to buy from transmigration farmers in Aimas. This is based on the inability to plant; besides, the land condition is a problem. The land with the topography of swamps allows native Papuan women to take the existing plants in the canals (waterways) occupied by kangkong plants without planting them. In contrast to the Aimas transmigration farmers, apart from developing traditionally, they also establish simple technology in growing from seeds that are traded on farms (Ramli, 2020). 


\section{b. Distributor}

The profession as a seller of water spinach, for Papuan mothers who buy from farmers, can be categorized as a distributor. They buy vegetables in the context of kale as merchandise to sell. Soekartawi stated that distribution distributes or delivers goods and services to be equal to the end consumer (Soekartawi, 2020). As shown in Figure 2 (1) above, $30 \%$ of Papuan mama sellers have obtained merchandise from farmers with a buying pattern.

\section{c. Seller}

Horticulture as an object of sale for mama Papua consists of fruit and banana leaves, sweet potatoes, vegetables in the form of kale, flowers, young leaves, and papaya fruit, Figure 2 (2). Their tendency to choose the type of horticulture shows that only for seasonal and short-term crops, except for areca nut, a seasonal plant, and a long-term plan because it can live from 25-30 years (Fadelfc, 2020). The percentage of vegetables (kale) ranks highest, followed by sweet potatoes, which, according to the local language, is called kasbi, strengthening Aimas' position as a vegetable center. The vegetable group includes kale, papaya flowers, banana blossoms, and bamboo shoots, while fruit includes papayas and bananas.

The selling experience, which led him to understand the concept of bargaining, is strongly suspected of being a socio-economic interaction with transmigrants and migrants or migrants. Ahmad Masaul commented on Papuan mothers' behavior in the mountainous district of Arfak, West Papua, who used an "angry" tone when prospective buyers bargained their merchandise. According to him, one of the markets does not recognize bargaining (Khoiri, 2018). The Papuan mama sellers' behavior is still found in the Aimas traditional market in responding to buyer behavior (Ramli, 2020). They tend to bring home merchandise selling below the base price or equal to the nominal bargaining price.

No literature can answer why Papuan mothers tend to choose the mentioned objects of sale. However, the research results show that they have access to these goods very quickly and cheaply, as shown in Figure 2, the majority of them come from their crops. Especially for areca nut, which is part of their needs, occupies the lowest position (10\%), because its consumption is limited to Papuan ethnic groups. The habit of chewing betel nuts is passed down from generation to generation from their parents and by residents of other ethnicities who are not accustomed to doing the same thing (Wugaje, 2020). The need for areca nuts is obtained by buying and selling and giving voluntarily among them.

\subsection{The Economic Impact of Horticulture on Families}

The income from the sale of native Papuan women is earmarked for the needs of their families. The study results show that four aspects of the "mama Papua" market's 
economic impact include the fulfillment of clothing and food, children's education, capital, and family savings.

\section{a. Fulfilment of Clothing and Food}

Fulfillment of clothing and food needs or known as meeting household needs, occupies the highest position in the economic impact of Mama Papua, which reaches $60 \%$. This shows that Papua's mother, apart from being the household economy's backbone, also has a domestic duty as a household controller in the relationship between husband and wife, wife, and children. This mama Papua position is relevant to Olson's view, who assesses that the traditional view of men and women's roles has begun to change towards egalitarianism. This idea is accompanied by the increasing role of men in carrying out household roles.

\section{b. Education}

Education becomes an authority in Papuan culture. The higher the education obtained by the family, the higher the social status for native Papuan families. Therefore, the "mama Papua" prioritizes the need for education for their children. Apart from getting fees from Otsus, Papuan women also set aside their income from trading for their children's education needs, see Figure 2 (3).

\section{c. Business Capital}

Lawrence J. Gitman said that capital is a long-term loan owned by a company or anything on the right side of the company's balance sheet other than liabilities (Lawrence, 2020). Capital is an asset that can support production so that money is seen as one of the assets that can be used as business capital in the context of Mama Papua. The need for money, by mama Papua in carrying out business activities. Figure 2 (4) above shows that the capital originating from profits only reaches $10 \%$ so that in the other figure, it is stated that the source of capital is $70 \%$. It is stated as its own capital. This percentage of capital sources does not mean that they have the capacity of capital in terms of money, but they understand it as an asset owned in the form of goods and labor. Another percentage stated that $70 \%$ stated that they developed their business with their capital, while $30 \%$ indicated that they had capital from others (Lawrence, 2020).

\section{d. Family Savings}

Dwi Mutiara stated that savings are a part of income that is not consumed (Mutiara, 2018). It is called family savings because of the income that the family does not consume. Are there family savings that come from Papua's income from the horticultural business? There is no definite answer. However, their desire to obtain additional business capital from family savings has been recognized as $40 \%$. 


\subsection{Islamic Financial Empowerment Offer}

There are two models of empowerment offers for "mama Papua" in carrying out the economic transformation. First, easy access to capital through zakat and infaq, and sustainable assistance by stakeholders. If these two instruments combine, the stretching of the traditional "mama Papua" market economy can be increased and compete with other communities.

\section{a. Access to Capital: Finance and Zakat and Infaq through Banks}

The financial donations offered to the original Kokoda mama Papua seller are muthlaqah and muqayyadah in nature. This is done to meet their capital needs. Their required capital, seen from the objective conditions of sale, can be grouped in. The use of money for them is allocated to purchase goods for sale. Figure 2 (4) above shows the need for business capital. The largest percentage in the table above is the capital allocated for the purchase of merchandise. This trend indicates that mama Papua needs money to buy groceries. This capital requirement can be done with two patterns of infaq that can be given to them, namely muthlaqah and muqayyadah (Hamzah, 2018). The subject of providing both of these patterns can be personal and institutional. Personally, namely, the owner of the funds directly gives to those concerned. The author seems that individual giving is not economical, and this argument will be explored in the section on building a business ethos.

\section{b. Economic Human Resource Development for Mama Papua: Assistance with Stakeholders}

\section{Building a Business Ethos:}

According to informants, the unprofessionalism of Mama Papua in the sense of dualism of work, namely as a land manager who is directly a farmer and at the same time as a seller, results in them not having a centralized concentration act as a seller (Umrah, 2020). Theoretically, salespeople need business skills to be trained in a focused manner. This dualism of work encourages them not to develop themselves optimally. Atkinson Patrick argues that professional salespeople, among others, can sell satisfactorily (Elqorni, 2008). That their condition of making sales is part of their ethos, but this ethos must be accompanied externally.

External assistance can be carried out by involving religious organizations and professional organizations facilitated by the Sorong district's empowerment office. Religious organizations are needed because, as religious people, a spiritual approach from religion is essential. Satria stated that the study of work ethics and religion by Weber The Protestant Ethic and the Spirit of Capitalism (1958), said that studies emerged by confirming the positive relationship between belief systems and prosperity (Lubis, 2013). Strengthening the religious ethos of business ethos, apart from the above arguments, is also supported by the fact that Papua's mama has family responsibilities as an economic argument. 
Economic Attitude Growth:

According to informants, mama Papua experiences cultural factors that cause her not to develop her selling ability. The cultural factor is that those who have must share with families in need. The implication is that those who do not have will feel free to take from the large family's assets that do have it (Ramli, 2020). Their togetherness in the economic aspect is high, but they are considered unproductive.

In Islamic finance, the concept of infaq is known. This concept encourages property owners to act as distributors or infaq of part of their assets. With a distributor's attitude, he is motivated to continue to work hard so that the attitude as a distributor or infaq is carried out continuously. On the other hand, donations recipients will feel burdened by the assets they have acquired. Strengthening the concept of infaq by reconstructing thoughts on unproductive togetherness is a strategic step in changing their economic meaning pattern.

\section{Selling Skills:}

\section{- Business communication}

An era of disruption caused by globalization does not seem to have a significant influence on cultural change. By Huntington (1996), after the cold war, differences between nations no longer occur from an ideological and economic perspective but a cultural side (Terry, 1972). According to him, clashes can occur from several major civilizations, and this is influenced by a person's entity defining oneself based on ancestors, religion, and customs. Furthermore, Richard follows Awuy's opinion that countries involved in communication in globalization do not necessarily adhere to a single ideology. Still, new awareness emerges in the search for regional ethnics.

Following the description above, mama Papua, as part of the representation of OAP (indigenous Papuans) who live amid the differences between ethnic groups in Aimas and the globalization era, will be relevant to Huntungkton and Away's views. On that basis, the business communication that they often do when selling, as described earlier, should be a potential attraction for buyers from different ethnic groups (Bugis, Javanese, Makassar, Sundanese, Manado, etc.). To transform it, they need to provide insight into cross-cultural business communication.

\section{Bargaining concept}

In his book, Kotler views negotiation or bargaining in marketing (marketing channels reach agreement on price and other terms so that transfers of owners have or possession can be effected). According to him, the function of associating is to produce an agreement on the price between the owner and the buyer to achieve a significant transfer of ownership rights (Kotler, 2003). This function is useful if both parties (buyers and sellers) can understand bargaining as part of the buying and selling concept. The data previously presented by Mama Papua did not fully understand the idea of negotiation. As a result, buyers are unable to obtain price information as a result of the talks. Strengthening insight into talks as part of buying and selling is important for Papuan mothers to optimize their sales. 
Figure 3. Model of Empowerment of Indigenous Papuan Women Towards Economic Development

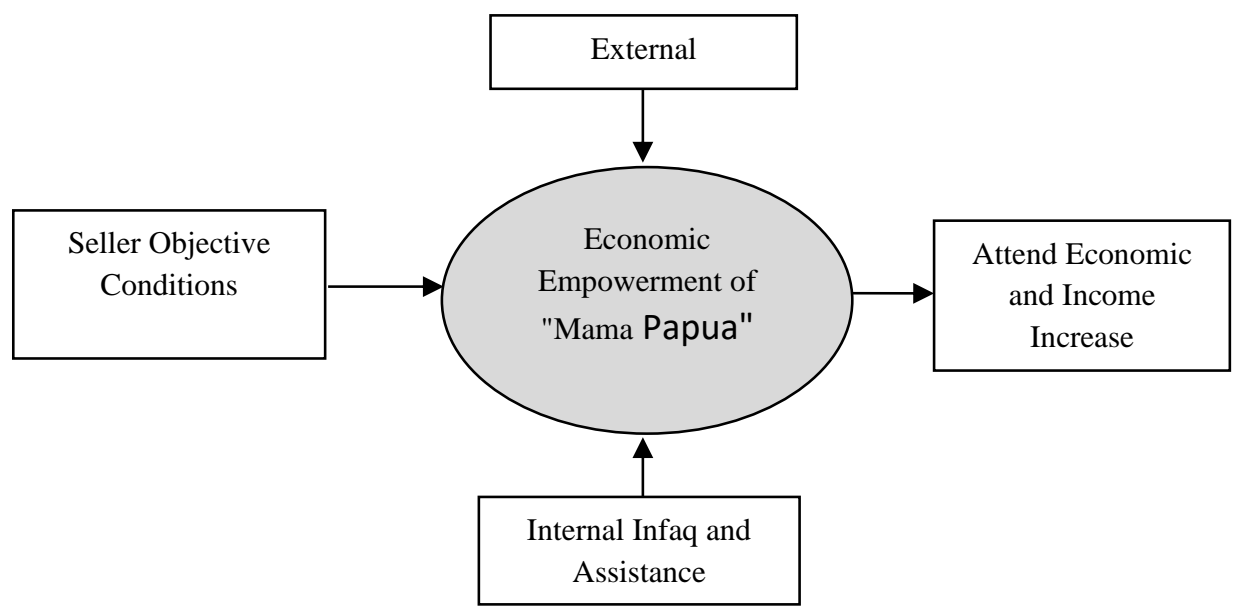

Source: Own creation.

Muhammad Baqir Shader put forward the theory of pre-production distribution (nadhariyyah tauzi 'ma qabla al-Intaj). According to him, work is the only basis in primary ownership rights over natural resources (Shader, 20280). Furthermore, this theory recognizes individual ownership of natural resources because of their work's implications or the efforts to use them directly and sustainably on natural resources.

This research strengthens this theory because mentoring and providing capital through donations, as economic empowerment for mama Papua, substantially increases work. Another idea that is considered relevant is (Hamzah, 2015) that work ethic is an effort to implement other Islamic teachings. Rewards, known as rewards or wages and torment, can be obtained from the work ethic. This research implies that building a work ethic can be driven through external factors. The external factor is the mother of Papua's contribution in the form of donations and assistance. Without an external grant, it will be difficult for an increase in work ethic to be developed.

\section{Conclusion}

This research shows that native Papuan women "mama Papua" has a dual role in the family. Apart from being a housewife, she is also the backbone in fulfilling her family life. Meeting the needs of the family is done by trading horticulture (garden produce). Ironically, trade is carried out in a very traditional manner or is more towards the inability to compete with non-Papuan sellers (transmigration or immigrants). The traditional trading model of the "mama Papua" places them in the lowest economic status. The low level of knowledge in marketing and government support is the leading cause of economic expansion. Finally, put "mama Papua" on a challenging condition in obtaining more profit from trading. 
This research shows the various forms of responsibility for native Papuan women in fulfilling the family economy. In addition to clarifying where the economic resources are obtained, it is also how the impact will be in supporting the family. Besides that, the merchants' hopes are also a concern and interesting findings in this study. The current study lacks an analysis of the long-term impact of indigenous Papuan women's traditional trade model, particularly the indigenous Papuan women of the Kokoda tribe. This study found an empowerment model that was deemed effective so that native Papuan women were more empowered. Capital support and assistance are their priority to be more independent in economic expansion (trade).

Based on existing research results, an offer that could be an option is to facilitate access to capital (zakat and infaq), which is given directly to mama Papua. Capital is considered a useful tool to encourage growth and stretch the economy of traditional market players. Access to capital can be made directly by the penginfaq or through formal infaq institutions in the region. Also, continuous assistance from various elements (stakeholders) is related to resource development. Strengthening the growth of business ethos and selling skills can be a priority for mentoring. Furthermore, researchers realized the weaknesses in the research carried out. The existing informants are still focused on the "mama Papua" of the Kokoda tribe. Meanwhile, in Papua, there are many ethnic groups related to indigenous Papuan women to strengthen the economy. Further research can consider each tribe's representation so that the picture of indigenous Papuan women's empowerment in economic transactions can be seen more comprehensively.

\section{References:}

Ahmed, E.M., Ammar, A. 2015. Islamic Microfinance in Sudanese Perspective. J Bus Fin Aff, 4(149), 234-2167.

Blesia, J.U., Ratang, W. 2016. Indigenous Wisdom for Developing Economic Life Case of Yokari People, West Papua. Komunitas: International Journal of Indonesian Society and Culture, 8(2), 275-284.

Chotim, E.E. 2020. Perempuan Pedagang Papua di Perbatasan. Sosiologika: Jurnal Sosiologi Pembangunan Indonesia, 1(1), 21-33.

Datu, S. 2020. Wawancara: Tokoh Papua atas ekonomi Perempuan Asli Papua.

Elqorni, A. 2008. Profesionalisme dalam Penjualan. Retrieved from: https://elqorni.wordpress.com/2008/05/30/profesionalisme-dalam-penjualan/.

Fadelfc. 2020. Umur Pohon Pinang Berbuah dan Bagaimana Proses Panennya. Lentera Mantang. Retrieved from: https://www.bibitpinangunggul.com/2019/08/umurpohon-pinang-berbuah-dan-bagaimana-proses-panen-buah-pinang.html.

Gundogdu, A.S. 2018. An inquiry into Islamic finance from the perspective of sustainable development goals. European Journal of Sustainable Development, 7(4), 381.

Hamzah, H. 2015. Ekonomi Islam: Keuangan Bisnis dan Sosial. Kaukaba Dipantara. Hasibuan, M.S. 1987. Ekonomi Pembangunan Dan Perekonomian Indonesia, Armico. Jppn.com. 2018. Program Pondok Pinang Buat Mama Papua Senang. JPNN.Com. Retrieved from: https://www.jpnn.com/news/program-pondok-pinang-buat-mama-papuasenang.

Khoiri, A.M. 2018. Berani Menawar, Bisa Dimaki Emak-emak Papua di Pasar Ini. 
DetikTravel. Retrieved from: https://travel.detik.com/fototravel/d-4195027/fotoberani-menawar-bisa-dimaki-emak-emak-papua-di-pasar-ini/7.

Kotler, P. 2003. Manajemen Pemasaran. edisi kesebelas. In Indeks kelompok Gramedia. Lawrence. 2020. Pengertian Modal : Sumber Modal dan Jenis Modal. Jagad.Id. Retrieved from: https://jagad.id/pengertian-modal-menurut-para-ahli-sumber-modal-dan-jenismodal/\#: :text=Lawrence J. Gitman mengatakan bahwa,perusahaan selain kewajiban saat ini.

Lubis, S.H. 2013. Aspek-Aspek Etos Kerja Dan Faktor-Faktor Yang Mempengaruhinya. Poltek Keuangan Negara STAN. Retrieved from: http://www.pknstan.ac.id/article/aspek-aspek-etos-kerja-dan-faktor-faktor-yangmempengaruhinya.

Miles, M.B., Huberman, A.M., Huberman, M.A., Huberman, P.M. 1994. Qualitative Data Analysis: An Expanded Sourcebook. SAGE Publications. https://books.google.co.id/books?id=U4lU_-wJ5QEC.

Mutiara, D. 2018. Tabungan, Giro, Deposito (Simpanan Berjangka). Dwimutiara. Retrieved from: https://dwimutiara.wordpress.com/2012/06/05/pengertian-tabungan-girodeposito-simpanan-berjangka/.

Nugroho, L., Chowdhury, S.L.K. 2015. Mobile Banking for Empowerment Muslim Women Entrepreneur: Evidence from Asia (Indonesia and Bangladesh). Tazkia Islamic Finance and Business Review, 9(1).

Pahri, P. 2017. Model pemberdayaan ekonomi perempuan Papua melalui majelis Rakyat Papua: Studi Kasus Masyarakat Perempuan Asli Papua di Kota Jayapura. Universitas Islam Negeri Maulana Malik Ibrahim.

Rahayu, N.S. 2020. The Intersection of Islamic Microfinance and Women's Empowerment: A Case Study of Baitul Maal Wat Tamwil in Indonesia. International Journal of Financial Studies, 8(2), 37.

Ramli, M. 2020. Wawancara, Perspektif Masyarakat atas Produk Penjualan Mama Papua.

Samori, S. 2019. Sorong Investmen Gate. Micepro Indonesia.

Shader, M.I.B. 2020. Al-maktabah Asy-syamilah V-I. Kutubul al-Mutun : Sunan Ibnu Majah.

Soekartawi. 2020. Distribusi - Menurut Para Ahli, Saluran, Contoh, Tujuan, Macam \& Teorinya. Dosen Pendidikan. Retrieved from: https://www.dosenpendidikan.co.id/distribusi/.

Suryawan, I.N. 2017. Tak Cukup Bagi Kami untuk Meratap, Kami harus Berjuang: Kemandirian Mama-Mama dalam Dinamika Pemekaran Daerah di Tanah Papua. Umbara, 1(2).

Terry, G.R. 1972. Principles of Management. Richard D. Irwin Homewood.

Umrah. 2020. Wawancara: Tokoh Perempuan atas Pengelolaan Pemasaran Perempuan Asli Papua.

Wambrauw, L.T., Martin, S., Addison, R. 2019. The Nature of Papuan Women Indigenous Entrepreneurship in Informal Agricultural Sector (A Case of Papuan Women Traders in Manokwari and Surrounding Areas of West Papua-Indonesia).

SALASIKA: Indonesian Journal of Gender, Women, Child, and Social Inclusion's Studies, 2(1), 77-94.

Wugaje, A.J. 2020. Wawancara: Tokoh Papua, Model Pendanaan Usaha Perempuan Asli Papua.

Wulan, D.P.A., Muafa, I.W. 2020. Pola Pikir Masyarakat Asli Papua Dalam Peningkatan Daya Saing Perekonomian. Jurnal Ilmu Ekonomi \& Sosial, 11(1), 57-65. 